\title{
Smart Grid Untuk Efisiensi Konsumsi Listrik Pada Proses Produksi Di Industri Manufaktur
}

\author{
Agung N. Pramudhita, Puteri A. N. Mawangi
}

\begin{abstract}
Abstrak- Listrik sebagai sumber utama daya digunakan mulai dari pemenuhan kebutuhan harian dalam rumah sampai perindustiran. Di Indonesia kebutuhan listrik dipenuhi oleh PLN. Pelayanan PLN yang sering memadamkan listrik bergilir dan terkadang tanpa pemberitahuan menimbulkan kerugian yang besar pada Industri. Energi listrik harus dihasilkan melalui pembangkit listrik/power plants (PLN di Indonesia) atau pembangkit dari energi terbarukan (tenaga angin, tenaga matahari, dll). Kemudian didistribusikan ke industri, pemukiman penduduk dan kebutuhan umum. Untuk mengatur distribusi itu diperlukan control center yang mengaplikasikan Smart Grid. Teknologi Smart Grid yang menjadi perhatian sekarang difokuskan pada pengembangan metode menganalisis dan memvisualisasikan kumpulan data yang diolah. Smart Grid terdiri atas 3 unsur penting, yakni teknologi informasi, telekomunikasi dan tenaga listrik. Ketiga unsur tersebut bekerja sama untuk memungkinkan adanya komunikasi 2 arah antara utility company seperti PLN dengan konsumen. Konsep Smart Grid sudah diimplememtasikan jauh sebelum Indonesia mengenal Smart Grid. Terbukti sukses di negara maju dan memungkinkan untuk diimplementasikan di Indonesia

Kata Kunci - Control Center; Industri, Listrik; Smart Grid.
\end{abstract}

Abstract - Electricity, as the main source of power, is used to fulfill daily needs in the house to industry. In Indonesia, electricity needs are provided by PLN. The PLN service, which often turns off electricity in turns and sometimes without notification, causes huge losses to the industry. Electrical energy must be generated through power plants (PLN in Indonesia) or generation from renewable energy (wind power, solar power, etc.). Then distributed to industry, residential areas and public needs. To manage the distribution, a control center that applies the Smart Grid is needed. Smart Grid technology that is of concern is now focused on developing methods of analyzing and visualizing the processed data sets. Smart Grid consists of 3 important elements, namely information technology, telecommunications and electric power. The three elements work together to enable two-way communication between utility companies such as PLN and consumers. The Smart

A. N. Pramudhita is with the Information Technology Departement of State Polytechnic of Malang, Malang, Indonesia (corresponding author provide phone +6281334699967; email agung.pramudhita@polinema.ac.id)

P. A. N. Mawangi., is with Department of Mechanical Engineering Education, Malang, Indonesia.( e-mail: puteriardista95@gmail.com).
Grid concept was implemented long before Indonesia introduced the Smart Grid. Proven success in developed countries and allows it to be implemented in Indonesia

Keywords - Control Center; Industry, Electricity; Smart Grid.

\section{Pendahuluan}

$\mathrm{K}$ EHIDUPAN modern saat ini sangat tidak memungkinkan tanpa adanya energi listrik. Listrik sebagai sumber utama daya untuk gadget, komputer, mesin dan barang elektronik lainnya digunakan pada tingkatan rumahan sampai industri. Misalnya dirumah tangga, pertokoan, perkantoran, pabrik, rumah sakit, sekolah, dijalanan, ataupun ditempat-tempat umum lainnya. Di Indonesia kebutuhan listrik dipenuhi oleh PLN. PLN merupakan perusahaan Badan Usaha Milik Negara (BUMN), sehingga penggunaan listrik sebagian besar masih disubsidi pemerintah. Pelayanan PLN yang sering memadamkan listrik bergilir dan terkadang tanpa pemberitahuan menimbulkan kerugian banyak pihak. Dunia industri sebagai pengguna listrik terbesar tentunya akan merasakan dampak yang paling besar apabila ada pemadaman listrik. Kerugian yang diderita tentunya tidak sedikit. Menurut kompas.com (1/10/2009) akibat pemadaman listrik bergilir, dunia usaha di Jakarta rugi Rp 100 miliar setiap harinya [1]. Pemadaman di salah satu kota bisa rugi ratusan milyar, belum lagi dengan kota-kota lain yang jumlahnya ratusan. Maka apabila dikalkulasi kerugian yang dialami dunia industri seIndonesia mencapai angka Triliunan setiap terjadi pemadaman listrik.

Dari segi kapasitas penyediaan listrik yang dimiliki oleh PLN terbukti tidak mampu menampung konsumsi listrik. Baru pada bulan Agustus 2017 PLN melakukan kerjasama dengan pihak swasta dengan 53 produsen listrik swasta [2]. Hal ini membuktikan keterlambatan langkah pemerintah dalam menghadapi krisis energi di Indonesia. Krisis energi listrik terjadi akibat konsumsi listrik yang meningkat. Semakin tinggi pendapatan masyarakat, tingkat konsumsi non makanan seperti hiburan (elektronik, TV, gaming, internet, dll) juga meningkat. Selain itu meningkatnya industri manufaktur di Indonesia juga menyumbang peningkatan konsumsi listrik yang besar. Menurut data dari Kementerian Perindustrian Negara Indonesia antara tahun 2009 sampai 2013 ada peningkatan sebesar $15,51 \%$ untuk industri pengecoran besi dan baja, 14,06\% untuk 
industri pembuatan logam dasar bukan besi, 17,78\% industri besi dan baja dasar (iron and steel making), dsb [3]. Pada tahun 2016 Badan Pusat Statistik (BPS) telah melakukan Sensus Ekonomi. Dari hasil sensus, jumlah perusahaan di Indonesia tercatat ada sebanyak 26,7 juta. Angka ini meningkat dibanding hasil Sensus Ekonomi 2006 yang sebanyak 22,7 juta perusahaan. Artinya, ada 3,98 juta perusahaan baru dalam 10 tahun terakhir. Jumlah perusahaan pada Sensus Ekonomi 2016 ini meningkat $17,51 \%$ dibanding dengan jumlah pada 2006 [4]. Proyeksi konsumsi listrik tentunya sudah didata, namun tindakan preventif masih belum dilakukan. Akhirnya solusi praktis yang ditempuh adalah pemadaman listrik bergilir dan kerjasama dengan produsen swasta yang masih baru dilakukan oleh PLN.

Sebagian besar pembangkit listrik yang beroperasi di dunia menggunakan bahan bakar fosil, begitu juga dengan Indonesia. Padahal, cadangan bahan bakar fosil semakin lama semakin menipis dan diperkirakan akan segera habis. Pada World Economic Forum 2010, terungkap bahwa pembangkit listrik berbahan bakar batubara di US menyumbang $40 \%$ emisi karbon di negara tersebut [5]. Ketersediaan energi listrik yang cukup merupakan hal yang harus dijaga demi keberlangsungan hidup manusia. Maka solusi terbaik yang sangat mungkin dilakukan adalah Smart Grid. Smart Grid menjadi jawaban sejak 3 tahun terakhir ini [5]. Smart Grid merupakan suatu konsep tata kelola energi listrik yang mampu mengakomodir peran pembangkit listrik kecil berbahan bakar energi terbarukan secara optimal. Berdasarkan hal tersebut dengan penggunaan Smart Grid di industri dapat memanajeman konsumsi listrik sesuai kebutuhan industri khususnya konsumsi listrik dalam proses produksi.

\section{LANDASAN TEORI}

Dari latar belakang diatas terdapat beberapa dasar teori yang akan dibahas, berikut penjelasannya.

\section{A. Smart Grid}

Secara umum Grid bisa diartikan sebagai jaringan listrik, pada IEC tahun 2010 Smart Grid didefinisikan sebagai jaringan listrik pintar yang mampu mengintegrasikan aksi-aksi atau kegiatan dari semua pengguna, mulai dari pembangkit sampai ke konsumen dengan tujuan agar efisien, berkelanjutan, ekonomis dan suply listrik yang aman [6]. Mengintegrasikan didalam Smart Grid berarti mengkoneksikan antara produsen dan konsumen. Pengembangan teknologi Smart Grid berawal dari usaha maksimal untuk memberdayakan apapun yang tersedia di bumi ini. Pada dasarnya konsep dari Smart Grid ini bisa menghasilkan beberapa keuntungan. Misalnya, meningkatnya efisiensi penggunaan energi listrik, meningkatnya kehandalan sistem tenaga listrik, mengurangi emisi karbon dan mendukung pemanfaatan sumber energi terbarukan dengan lebih optimal.

Smart Grid terdiri atas 3 unsur penting, yakni teknologi informasi, telekomunikasi dan tenaga listrik. Ketiga unsur tersebut bekerja sama untuk memungkinkan adanya komunikasi 2 arah antara utility company seperti PLN dengan konsumen. Dengan Smart Grid, transfer energi listrik yang terjadi tidak hanya dari perusahaan penyedia listrik ke konsumen, namun juga sebaliknya. Jika ternyata konsumen memiliki solar cell yang dapat menghasilkan energi listrik dari cahaya matahari, maka ketika energi listrik dari solar cell itu melebihi dari besar kebutuhan konsumen itu, maka konsumen bisa mengirim energi listrik ke grid yang ada. Konsumen bisa mendapatkan uang dari utility company atas hal tersebut. Adanya teknologi Smart Grid memungkinkan konsumen memiliki kendali penuh untuk mengatur konsumsi listrik [5].

Menurut Yu, Liau dan Qin [7] dalam hal jaringan listrik, pengembangan Smart Grid tersebut bertujuan untuk mencapai setidaknya empat tujuan utama:

- keamanan pengoperasian jaringan tenaga besar di bawah gangguan, meminimalkan risiko pemadaman listrik, dan ketahanan yang ditingkatkan

- akomodasi yang mulus dan pemanfaatan yang efisien sejumlah besar sumber energi terdistribusi

- fasilitasi pasar tenaga listrik maju dan respon permintaan

- penyediaan tenaga listrik dengan kehandalan tinggi, kualitas tinggi, dan efisiensi tinggi untuk digital masyarakat.

\section{B. Industri}

Menurut UU No. 5 Tahun 1984 tentang Perindustrian, INDUSTRI adalah kegiatan ekonomi yang mengolah bahan mentah, bahan baku, barang setengah jadi, dan/atau barang jadi menjadi barang dengan nilai yang lebih tinggi untuk penggunaannya, termasuk kegiatan rancang bangun dan perekayasaan industri [8]. Dalam KBBI [9] industri diartikan sebagai kegiatan memproses atau mengolah barang dengan menggunakan sarana dan peralatan, misal mesin. Sedangkan manufaktur adalah suatu cabang industri yang mengaplikasikan mesin, peralatan dan tenaga kerja dan suatu medium proses untuk mengubah bahan mentah menjadi barang jadi yang memiliki nilai jual. Pada dictionary Cambridge mengartikan "manufacturing industry is an industry that produces goods rather than services, or these industries considered as a group", yang artinya Industri manufaktur adalah industri yang memproduksi barang bukan jasa, atau industri ini dianggap sebagai suatu grup/perusahaan [10]. Dari definisi diatas dapat disimpulkan bahwa industri manufaktur adalah bagian dari industri dalam arti umum. Pada industri manufaktur 3 hal yang selalu berkaitan adalah input, proses dan output/produk yang dihasilkan. Dari tiga hal tersebut, topik yang dibahas secara spesifik pada kajian ini adalah tentang proses. Dimana proses pada industri manufaktur berarti proses produksi barang. Menurut Ahyari [11] proses produksi adalah suatu cara, metode ataupun teknik untuk menambah kegunaan suatu barang dan jasa dengan menggunakan faktor produksi yang ada, seperti tenaga kerja, mesin, bahan baku dan dana agar lebih bermanfaat bagi kebutuhan manusia. 
Proses produksi dilihat dari arus (flow) bahan mentah sampai menjadi produk akhir, terbagi menjadi dua macam, yaitu:

- proses produksi terus-menerus (Continous processes) adalah proses produksi barang atas dasar aliran produk dari satu operasi ke operasi berikutnya tanpa penumpukan disuatu titik dalam proses. Pada umumnya industri yang cocok dengan tipe ini adalah yang memiliki karakteristik yaitu output direncanakan dalam jumlah besar, variasi atau jenis produk yang dihasilkan rendah dan produk bersifat standar, contohnya perusahaan semen, tekstil, mobil, dan sebagainya

- proses produksi terputus-putus (Intermettent processes) yaitu, produk diproses dalam kumpulan produk bukan atas dasar aliran terusmenerus dalam proses produk ini. Perusahaan yang menggunakan tipe ini bisaanya terdapat sekumpulan atau lebih komponen yang akan diproses atau menunggu untuk diproses, sehingga lebih banyak memerlukan persediaan barang dalam proses. Contohnya meubel, pakaian, dan sebagainya

- proses produksi campuran, merupakan penggabungan dari proses produksi terus-menerus dan terputus-putus. Penggabungan ini digunakan berdasarkan kenyataan bahwa setiap perusahaan berusaha untuk memanfaatkan kapasitas secara penuh [12].

\section{Konsumsi Energi Listrik}

Konsumsi energi listrik yang dimaksudkan dalam kajian ini adalah pemakaian energi listrik yang kita gunakan. Baik digunakan secara produktif ataupun digunakan dengan sia-sia/ tidak produktif. Semakin besar dan berkembang industri maka kebutuhan energinya juga semakin besar [3]. Konsumsi listrik rata rata watt/kapita untuk Indonesia adalah 55,3 watt. Jauh jika dibandingkan dengan Amerika yang sebesar 1460 watt/kapita dan Jerman 753 watt/kapita. Menurut bisnis.liputan6.com [13] di Indonesia ada beberapa macam pelanggan industri. Mulai dari berdaya $450 \mathrm{VA}$ sampai berdaya lebih dari $30.000 \mathrm{KVA}$. PLN golongan tarif Industri di bedakan Menjadi 4 yaitu I1, I2, I3 dan I4 masing masing dibatasi dengan daya yang di daftarkan. Berikut penggolongannya:

- I1 daya 450 VA s/d $13900 \mathrm{VA}$

- I2 daya 13901 VA s/d 197 KVA

- I3 daya $197001 \mathrm{~s} / \mathrm{d}$ 13,32 MVA

- I4 bisa sampai tak terhingga (jika pasokan energinya cukup dan dengan persyaratan tertentu)

Pada sensus ekonomi oleh BPS pada tahun 2016 jumlah perusahaan meningkat $17,51 \%$ dibanding dengan jumlah pada 2006. Peningkatan jumlah perusahaan sebesar 3,98 juta [4]. Apabila dikalkulasikan, misalnya setiap perusahaan membutuhkan 2500 VA konsumsi listrik. Maka kenaikan konsumsi listrik sebesar 9725 juta VA atau 9,725 juta KVA yang harus disediakan oleh PLN, jumlah tersebut bisa kurang atau lebih. Oleh sebab itu konsumsi listrik pada industri/perusahaan harus diatur secara efektif dan efisien.

\section{METODE PENELITIAN}

Desain penelitian ini adalah Literature Review atau tinjauan pustaka. Penelitian kepustakaan atau kajian literatur (literature review, literature research) merupakan penelitian yang mengkaji atau meninjau secara kritis pengetahuan, gagasan, atau temuan yang terdapat di dalam tubuh literatur berorientasi akademik (academic-oriented literature), serta merumuskan kontribusi teoritis dan metodologisnya untuk topik tertentu. Adapun sifat dari penelitian ini adalah analisis deskriptif, yakni penguraian secara teratur data yang telah diperoleh, kemudian diberikan pemahaman dan penjelasan agar dapat dipahami dengan baik oleh pembaca.

\section{HASIL DAN PEMBAHASAN}

. Smart Grid memiliki tiga unsur penting agar bisa diimplementasikan, yaitu teknologi informasi, telekomunikasi dan tenaga listrik. Dimana implementasi Smart Grid ini dapat meningkatkan efisiensi konsumsi listrik pada proses produksi manufaktur. Menurut $\mathrm{Wu}$, Varaiya dan Hui [14] Smart Grid masa depan harus memenuhi visi energi internet di mana jutaan orang menghasilkan produk energi mereka sendiri dari energi terbarukan di rumah, kantor, dan pabrik mereka dan membaginya satu sama lain. Kendaraan listrik dan lokal. Penyimpanan energi akan banyak digunakan. Teknologi internet akan digunakan untuk mengubah jaringan listrik menjadi energisharing antar grid. Industri yang merupakan konsumsi listrik dengan daya besar sangat terbantu dengan penggunaan Smart Grid. Untuk lebih jelasnya lihat Gambar 1 [15].

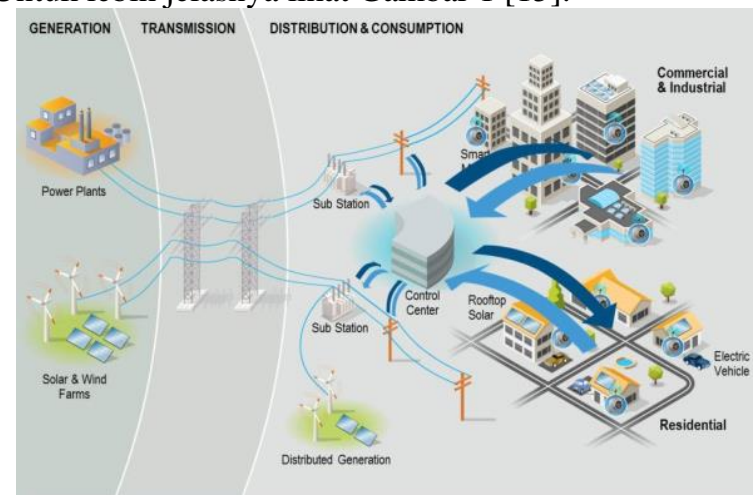

Gambar 1. Contoh penggunaan Smart Grid

Energi listrik harus dihasilkan melalui pembangkit listrik/power plants (PLN di Indonesia) atau pembangkit dari energi terbarukan (tenaga angin, tenaga matahari, dll). Kemudian didistribusikan ke industri, pemukiman penduduk dan kebutuhan umum. Untuk mengatur distribusi itu diperlukan control center yang mengaplikasikan Smart Grid. Smart Grid tersebut memungkinkan diimplemtasikan menggunakan koneksi internet. Pada proses produksi di Industri Manufaktur maka aplikasinya bisa dilihat pada Gambar 2 . 


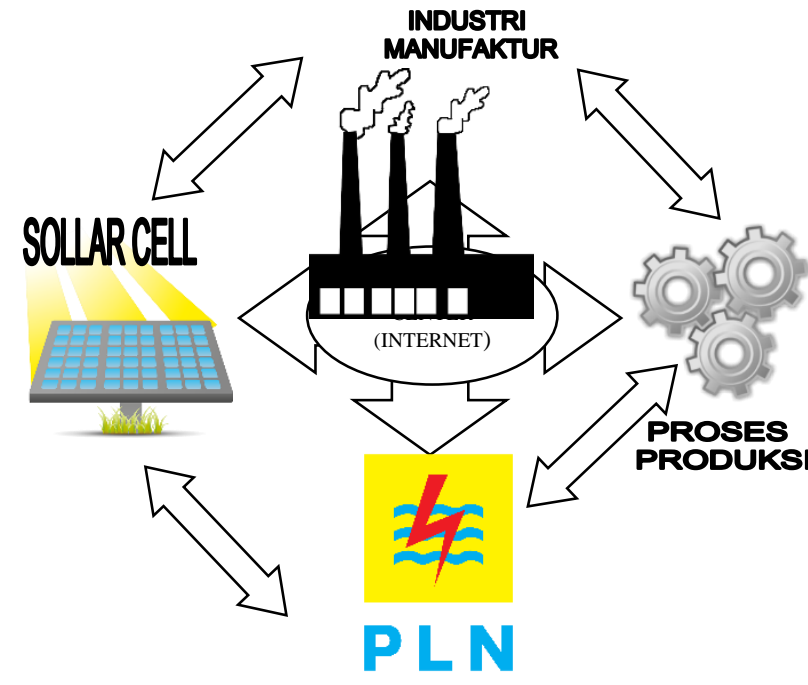

Gambar 2. Penggunaan Smart Grid pada proses produksi industri manufaktur

Setiap Industri manufaktur memiliki pembangkit energi terbarukan, misalnya tenaga surya. Energi dari tenaga surya diinformasikan melalui jaringan internet kepada industri dan PLN. Ketika siang hari energi listrik dari cahaya matahari cukup besar, sehingga listrik yang dihasilkan tenaga surya mampu mengaktifakan peralatan berat pada industri. Misalnya terdapat 5 mesin produksi, maka 5 mesin produksi tersebut akan aktif. Apabila energi listrik yang dihasilkan melebihi kebutuhan proses produksi maka melalui smart grid dapat disalurkan ke PLN dan industri bisa mendapat utility company berupa uang dari PLN. Apabila cahaya matahari mulai menurun, maka kontrol akan mengurangi pemakaian energi listrik. Misalnya mesin produksi yang aktif akan berkurang menjadi 4 atau tetap 5 yang aktif namun kekurangan energi listrik diambil dari PLN. Sehingga baik PLN maupun industri samasama diuntungkan. Disisi lain PLN mendapat pasokan energi listrik, dan industri mendapatkan tambahan income. Serta kebutuhan konsumsi bisa dapat diinformasikan secara langsung dengan komunikasi 2 arah, maka efisiensi konsumsi energi listrik bisa dipastikan akan efisien dan digunakan secara produktif. Dengan Smart Grid otomatis juga penghematan listrik, dam terhindar dari pemadaman listrik. Semua kekurangan dari jaringan listrik konvensional bisa diselesaikan oleh Smart Grid.

Sesuai pernyataan Shrivastava [15] perbedaan terbesar antara Smart Grid dan jaringan listrik konvensional adalah Smart Grid bersifat bi-directional, sehingga memungkinkan generasi terdistribusi dengan efisiensi yang lebih besar. Kelebihan daya yang dihasilkan pada beban, seperti dari sel surya di atap, turbin angin atau tenaga hidroelektrik yang dipompa dapat dimasukkan kembali ke Smart Grid. Fleksibilitas yang meningkat seiring dengan teknologi generasi berikutnya memungkinkan penetrasi yang lebih besar dari sifat sumber energi terbarukan yang sangat bervariasi sehingga bahkan tanpa penambahan penyimpanan energi, aplikasi dan kelayakan komersial mereka meningkat. Ini membantu mereka untuk memberikan output yang stabil setiap saat. Smart Grid membuat sistem tenaga listrik kita lebih tahan banting dan lebih siap menghadapi keadaan darurat seperti badai petir, gempa bumi, serangan teroris, flare matahari besar, dll. Smart Grid memungkinkan pengalihan rute secara otomatis saat peralatan gagal atau padam terjadi berkat diagnostik dan teknologi penyembuhan sendiri. Teknologi ini mendeteksi dan mengisolasi padam sebelum mereka berubah dalam skala besar. Fitur utama Smart Grid adalah kepintarannya itu sendiri, misalnya memastikan bahwa listrik menyala kembali dengan cepat dan strategis setelah keadaan darurat. Perutean listrik ke rumah sakit dan layanan darurat terlebih dahulu. Ada peningkatan kontrol konsumen saat seseorang menggunakan teknologi ini. Seseorang tidak lagi harus menunggu laporan bulanannya dalam tagihan untuk mengetahui berapa banyak listrik yang ia gunakan. Dengan meter cerdas dan mekanisme lain yang dipasang sebagai bagian dari sistem Smart Grid, seseorang dapat memiliki pandangan yang jelas tentang berapa banyak listrik yang ia gunakan dan biayanya dapat dilihat di aplikasi ponsel atau situs web. Ini mendukung penetapan harga dinamis real-time yang memungkinkan seseorang menghemat uang dengan menggunakan daya yang lebih rendah pada waktu di mana listrik paling mahal (permintaan lebih banyak). Dengan menggunakan teknologi ini, seseorang dapat menghemat lebih banyak tenaga dengan menjual energi surplus ke grid dengan menghasilkan listrik sendiri dengan penggunaan panel fotovoltaik atau kincir angin mini di teras atau halaman rumahnya, hal ini memungkinkan pengurangan permintaan yang tinggi terhadap konsumsi listrik dan membantu penyebaran listrik yang lebih seragam ([5], [7], [14], [15]).

Penyimpanan energi akan banyak digunakan. Teknologi internet akan digunakan untuk mengubah jaringan listrik menjadi energysharing antar grid Untuk mempersiapkan masa depan, Smart Grid dengan perifer cerdas, atau smart GRIP direncanakan. Bangunan blok arsitektur GRIP disebut sebuah sistem manajemen energi (EMS). Transmisi Grid Control didistribusikan ke grid inti, grid mikro, dan bangunan cerdas dan rumah di pinggiran. Arsitektur berlapis GRIP memungkinkan transisi tanpa batas dari sekarang ke masa depan dan plug-and-play interoperabilitas. Fungsi dasar sebuah cluster terdiri dari [14]:

- dispatch (pengiriman)

- smoothing (merapikan)

- mitigation (kemudahan/kelonggaran)

Ketika Smart Grid digunakan pada Industri manufaktur maka blok arsitektur GRIP dan EMS akan dibentuk secara perlahan. Pada lingkup kecilnya misalnya pada industri manufaktur itu sendiri. Bagaimana implementasi smart Grid digunakan dan bisa menjadi energysharing lihat Gambar 2.

Selain itu teknologi Smart Grid yang menjadi perhatian sekarang difokuskan pada pengembangan metode menganalisis dan memvisualisasikan kumpulan data yang diolah. Menurut Overbye dan Weber [16] survei tentang beberapa teknik visualisasi yang telah dikerahkan oleh industri tenaga listrik untuk memvisualisasikan data selama beberapa tahun terakhir. Teknik ini termasuk pie chart, animasi, kontur, grafik dengan variasi waktu, display berbasis geografis, pencampuran gambar, dan data teknik agregasi. 
Visualisasi ini penting karena untuk memantau kinerja Smart Grid itu sendiri, karena seperti yang dijelaskan diatas bahwa Smart Grid bisa digunakan dengan koneksi internet. Maka dengan terkoneksinya antar grid dan konsumen listrik baik yang memiliki grid terbarukan atau tidak banyak informasi data yang saling ditukar didalam control center dengan koneksi internet. Dengan data sebesar itu perlu visualisasi untuk keamanan dari kerusakan system, cyber crime, hack, kerusakan program, dan kontrol penggunaan listrik, dll. Gambar 3 dan 4 berikut merupakan contoh visualisasi data dari Smart Grid.

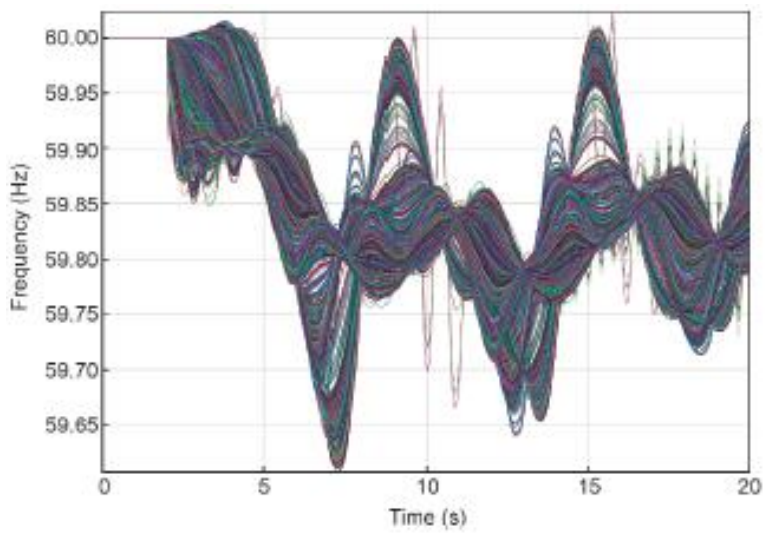

Gambar 3. Frekuensi generator system [16]

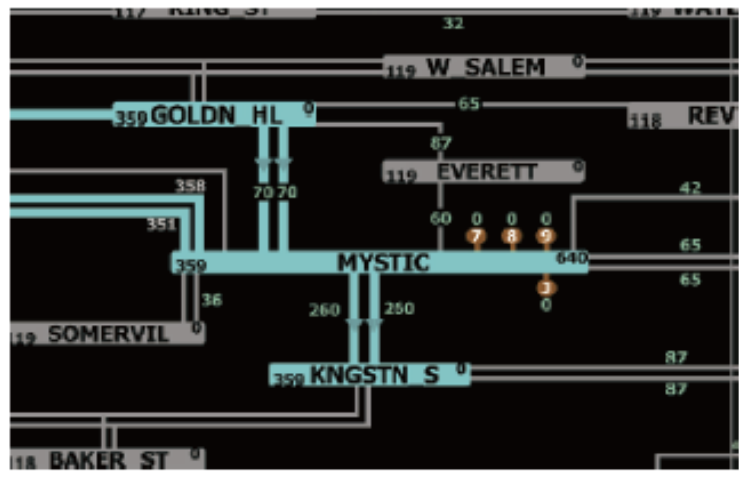

Gambar 4. Penggunaan objek tampilan ringkasan gardu [16]

Tempat visualisasi data tersebut terdapat operator yang menjalankan dari ruang control terpusat. Tergantung lembaga resmi yang menggunakan Smart Grid. Di Indonesia misalnya PLN. Dalam ruang kontrol selain tempat data-data diolah dan dilihat juga berperan sebagai tempat pengolah informasi mengenai sistem dan program yang berjalan. Gambar 5 berikut contoh gambar ruang kontrol dari Smart Grid.

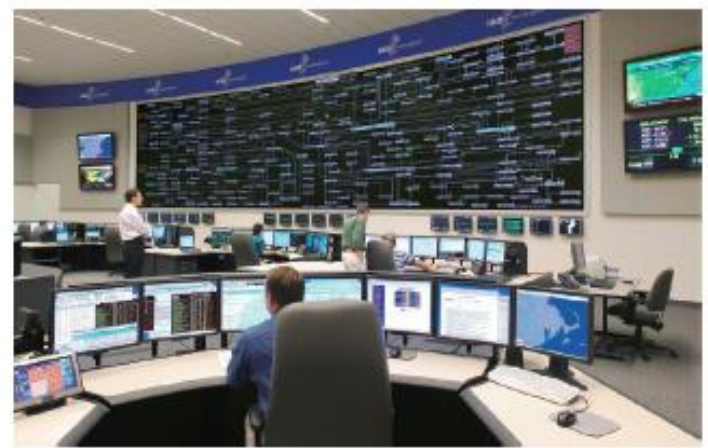

Gambar 5. Ruang kontrol Smart Grid di Inggris [16]
Konsep Smart Grid sudah diimplememtasikan jauh sebelum Indonesia mengenal Smart Grid. Terbukti sukses di negara maju Jerman dan Amerika yang mulai menerapkan konsep ini dan menyusul Inggris. World Economic Forum 2010 juga mengungkapkan bahwa SMART GRID ini mampu mengurangi emisi karbon sebesar $25 \%$ di negara itu ([5], [16]).

\section{KESIMPULAN}

Dari uraian diatas dapat disimpulkan bahwa teknologi Smart Grid sangat mungkin diimplementasikan di Indonesia khususnya pada Industri Manufaktur untuk meningkatkan efisiensi konsumsi listrik pada proses produksi. Selain itu Smart Grid merupakan konsep jaringan listrik berorientasi ramah lingkungan karena lebih mengutamakan penggunaan energi terbarukan dari pada energy dari fosil. Pada kenyataanya konsep Smart Grid sudah diimplementasikan di Jerman, Amerika dan Inggris dan terbukti sukses.

\section{REFERENSI}

[1] Kompas.com. (2009). Listrik Padam, Kerugian Setiap Hari Capai Rp 100 Miliar. [Online]. Tersedia: http://ekonomi.kompas.com/read/2009/10/01/08482526/listrik.p adam.kerugian.setiap.hari.capai.rp.100.miliar

[2] Marchel Agustinus. (2017). PLN Jelaskan Proses Kerja Sama dengan 53 Produsen Listrik Swasta. [Online]. Tersedia: https://finance.detik.com/energi/3583582/pln-jelaskan-proseskerja-sama-dengan-53-produsen-listrik-swasta

[3] Kementerian Perindustrian Negara Republik Indonesia. (2013). Statistik Jumlah Industri. [Online]. Tersedia: http://kemenperin.go.id/statistik/ibs_indikator.php?indikator=1

[4] Marchel Agustinus. (2017). Ada 3,98 Juta Perusahaan Baru di RI dalam 10 Tahun Terakhir. [Online]. Tersedia: https://finance.detik.com/berita-ekonomi-bisnis/3485474/ada398-juta-perusahaan-baru-di-ri-dalam-10-tahun-terakhir

[5] I Nyoman Yuliarsa. (2017). SMART GRID - Tata Kelola Sistem Tenaga Listrik Masa Depan. [Online]. Tersedia: http://ieeesb.ft.ugm.ac.id/smart-grid-tata-kelola-sistem-tenagalistrik-masa-depan/

[6] Pusat Penelitian dan Pengembangan Teknologi Ketenagalistrikan, Energi Baru, Terbarukan dan Konversi Energi. (2014). Teknologi Smart Grid merupakan basis Smart Energy. Tersedia: http://www.p3tkebt.esdm.go.id/index.php?option=com_content\&view=article\&id=787:teknologi-smart-grid-merupakan-basissmart-energy\&catid=147:kelistrikan\&Itemid=542\&lang=en

[7] Yixin Yu, Yanli Liu, Chao Qin, "Basic Ideas of the Smart Grid," Engineering, vol.1, hal. 405-408, Des. 2015.

[8] Undang-Undang Republik Indonesia No. 5 Tahun 1984

[9] Kbbi.kemdikbud.go.id. 2016. Arti Kata Industri. [Online]. Tersedia: https://kbbi.kemdikbud.go.id/entri/industri

[10] dictionary.cambridge.org. 2017. Dictionary Manufacturing Industry. [Online]. Tersedia: https://dictionary.cambridge.org/dictionary/english/manufacturin g-industry

[11] A. Ahyari. Manajemen Produksi: Perencanaan Sistem Produksi, Edisi 4, Cetakan Keempat. Yogyakarta:Penerbit BPF, 2002.

[12] William, "IDENTIFIKASI DAN PENYELESAIAN MASALAH PADA UKM MEUBEL,” JURNAL ILMIAH MAHASISWA AKUNTANSI., vol. 1, hal. 63-68, Mar. 2012.

[13] N.D Wahyuni. (2013). Daftar Lengkap Tarif Listrik Baru buat Pelanggan Industri. [Online]. Tersesdia: http://bisnis.liputan6.com/read/707938/daftar-lengkap-tariflistrik-baru-buat-pelanggan-industri

[14] Felix F. Wui, Pravin P. Varaiya, Ron S. Y. Hui, "Smart Grids with Intelligent Periphery: An Architecture for the Energy Internet," Engineering, vol. 1, hal. 436 -446, Des. 2015. 
[15] Aseem Srivastava. (2016). Can Smart Grid Transform the Indian Power Sector?. [Online]. Tersedia: http://www.ecoideaz.com/expert-corner/smart-grid-systems-inindia

[16] Thomas J. Overbye and James Weber, "Smart Grid Wide-Area Transmission System," Engineering, vol. 1, hal. 466 -474, Des. 2015. 